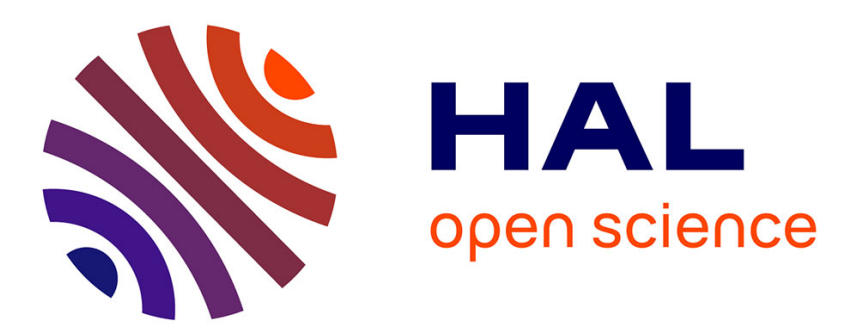

\title{
Controversial results of the genetic analysis of a canine distemper vaccine strain
}

Zoltán Demeter, Elena Alina Palade, Ákos Hornyák, Miklós Rusvai

\section{To cite this version:}

Zoltán Demeter, Elena Alina Palade, Ákos Hornyák, Miklós Rusvai. Controversial results of the genetic analysis of a canine distemper vaccine strain. Veterinary Microbiology, 2010, 142 (3-4), pp.420. 10.1016/j.vetmic.2009.10.017 . hal-00587286

\section{HAL Id: hal-00587286 \\ https://hal.science/hal-00587286}

Submitted on 20 Apr 2011

HAL is a multi-disciplinary open access archive for the deposit and dissemination of scientific research documents, whether they are published or not. The documents may come from teaching and research institutions in France or abroad, or from public or private research centers.
L'archive ouverte pluridisciplinaire HAL, est destinée au dépôt et à la diffusion de documents scientifiques de niveau recherche, publiés ou non, émanant des établissements d'enseignement et de recherche français ou étrangers, des laboratoires publics ou privés. 


\section{Accepted Manuscript}

Title: Controversial results of the genetic analysis of a canine distemper vaccine strain

Authors: Zoltán Demeter, Elena Alina Palade, Ákos Hornyák, Miklós Rusvai

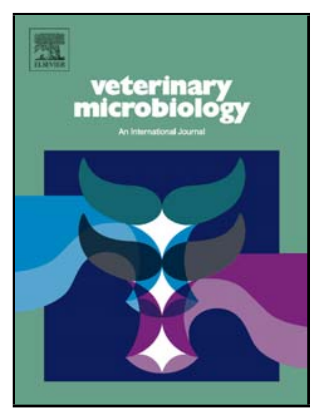

PII:

S0378-1135(09)00537-9

DOI: doi:10.1016/j.vetmic.2009.10.017

Reference: VETMIC 4645

To appear in:

VETMIC

Received date: 22-7-2009

Revised date: 5-10-2009

Accepted date: $16-10-2009$

Please cite this article as: Demeter, Z., Palade, E.A., Hornyák, Á., Rusvai, M., Controversial results of the genetic analysis of a canine distemper vaccine strain, Veterinary Microbiology (2008), doi:10.1016/j.vetmic.2009.10.017

This is a PDF file of an unedited manuscript that has been accepted for publication. As a service to our customers we are providing this early version of the manuscript. The manuscript will undergo copyediting, typesetting, and review of the resulting proof before it is published in its final form. Please note that during the production process errors may be discovered which could affect the content, and all legal disclaimers that apply to the journal pertain. 
2

4

\section{Controversial results of the genetic analysis of a canine distemper vaccine strain} (1)

Zoltán Demeter ${ }^{*}$, Elena Alina Palade ${ }^{1}$, Ákos Hornyák $^{2}$, Miklós Rusvai $^{1}$ (1)

${ }^{1}$ Department of Pathology and Forensic Veterinary Medicine, Szent István University, Faculty of Veterinary Science, H-1078 Budapest, István u. 2, Hungary

${ }^{2}$ Department of Microbiology and Infectious Diseases, Szent István University, Faculty of Veterinary Science, H-1143 Budapest, Hungária krt. 23-25, Hungary

*Corresponding author. Tel: +36-1-478-4178; +36-70-222-3365. Fax: +36-1-478-4284.

E-mail address: Demeter.Zoltan@aotk.szie.hu

\section{Abstract}

Canine distemper (CD) is a highly contagious, often fatal, multisystemic viral disease of receptive carnivores. The presence of a PsiI cleavage site on a specific location of the hemagglutinin $(\mathrm{H})$ gene was found to be a hallmark of vaccine strains, thus, a previously published restriction fragment length polymorphism (RFLP) test using Psi theoretically allows the distinction between all currently used vaccine strains and virulent field strains. The RFLP test was carried out on all brands of CD vaccines available in Hungary. The present work describes the extensive sequencing and phylogenetic study of the strain present in Vanguard (Pfizer Animal Health) vaccines, which following the PsiI based RFLP test reacted as a wild-type strain. Based on the product description provided by the manufacturer, all batches should have contained a virus strain (Snyder Hill) belonging to the group of vaccine strains (America-1). Extensive genetic analysis involving the full nucleic acid sequence of four other genes $(\mathrm{N}, \mathrm{M}, \mathrm{P}$ and $\mathrm{F})$ of the $\mathrm{CDV}$ genome revealed that the incriminated virus 
1 strain showed a higher level of genetic identity to wild-type strains from the America-2 group

2 than to any of the strains belonging to America-1 group, therefore the vaccine does not

3 contain the virus strain stated by the manufacturer in its product description and has not been

4 containing it since at least 1992.

6 Keywords: canine distemper, vaccine strain, phylogenetic analysis

$8 \quad$ Running title: Canine distemper vaccine strain ambiguity

\section{Introduction}

11 Canine distemper (CD) is a highly contagious viral disease that has a wide range of receptive carnivore animal families, such as the Canidae, Mustelidae, Procyonidae, Felidae and many others. It is caused by the canine distemper virus (CDV) which belongs to the Morbillivirus genus of the Paramyxoviridae virus family (Appel, 1987; Kabakci et al., 2004; Lednicky et al., 2004). Although live attenuated vaccines have been used for many years to control distemper (Chappuis, 1997; Barrett, 1996; Patel \& Heldens, 2009), CDV continues to cause outbreaks in receptive domestic carnivores all around the world, in particular young dogs in breeding units and shelter facilities which most often suffer fatal disease (Appel, 1987; Blixenkrone-Møller et al., 1993; Barrett, 1996; Gemma et al., 1996; Demeter et al., 2006; Martella et al., 2008). Previous genetic and phylogenetic studies have revealed that the virus strains used in the currently applied vaccines form a distinct group (America-1) from the large group of wild-type strains that were reported worldwide in the previous decades (Martella et al., 2007; Demeter, 2009). The most frequently used strains in the manufacturing process of CDV vaccines are the Onderstepoort, Snyder Hill, Rockborn, Lederle, and Convac. The 
1 outbreak among North American ranched foxes in the 1930's (Haig, 1956; Martella et al., 2 2007). The Snyder Hill strain was isolated in Ithaca, USA in the 1950's from the brain of a 3 dog. The virus was then passaged in vivo in dogs before being adapted to cell growth in NL4 DKC cells (Brown et al., 1972; Martella et al., 2007). The Rockborn strain is 5 undistinguishable from the Snyder Hill strain (Greene \& Appel, 2006), while all the other 6 vaccine strains (Lederle, Convac etc.) also belong to the America-1 group. Nowadays it is not 7 clear whether these strains are still circulating in the field, since they have not been detected over the last five decades (Martella et al., 2007).

In recent years the number of vaccinated dogs that got infected with CDV and developed characteristic clinical signs of CD has increased (Appel, 1987; Blixenkrone-Møller et al., 1993; Kai et al., 1993; Shin et al., 1995; Gemma et al., 1996; Lan et al., 2006). The molecular analysis of the isolates from the vaccinated yet infected canines demonstrated that the causative agent in these cases was not closely related to any of the currently used vaccine strains (Pardo et al., 2005; Lan et al., 2006; Calderon et al., 2007; Martella et al., 2007). On the other hand, cases when vaccinated animals shed the vaccine strain for a limited period of time were also described (Greene \& Appel, 2006). Considering the fact that in case of recently vaccinated animals the virus strain present in the vaccine can interfere with polymerase chain reaction (PCR) based diagnostic tests, leading to diagnostically false positive results, in order to rule out the mentioned misleading factors, a PCR coupled with restriction fragment length polymorphism (RFLP) assay using a PsiI cleavage site of the

21 hemagglutinin $(\mathrm{H})$ gene of the viral genome was designed (Demeter et al., 2007). According to the nucleotide sequences deposited in the publicly accessible GenBank, the presence of Psi cleavage site is characteristic only for vaccine strains, thus, Psi RFLP was expected to allow a reliable differentiation of all CDV vaccine strains from the wild-type ones. During the examination of CDV vaccines marketed in Hungary by Psi RFLP, the vaccine strain present 
1 in a Vanguard vaccine (Pfizer Animal Health, USA) exhibited wild-type genetic feature

2 remaining undigested by $P$ siI. This study presents the results of the extensive sequencing and

3 phylogenetic investigation of batches of this vaccine brand purchased in different countries

4 (Hungary, Malta, Israel, and USA), as well as batches dating back to 1992 and 1994.

6 2. Materials and methods

\section{2.1. Vaccine batches}

8 Products of four different manufacturers were purchased and tested during this study. A total

9 number of ten vaccines were investigated, of which six were of the same brand (vaccines number 1 to 6), but purchased in different countries (Hungary, Israel, Malta and United States of America) or were from batches dated back to 1992, 1994 and 2006 (Table 1). All modified live $\mathrm{CD}$ vaccines were stored at the recommended temperature of $4{ }^{\circ} \mathrm{C}$.

\subsection{RNA purification}

Vaccines were prepared according to the protocol provided by each manufacturer. Following dilution of the lyophilized component with the solution recommended and supplied together with the vaccine, viral RNA was isolated from each vaccine using QIAamp viral RNA Mini Kit (Qiagen, Germany) according to the manufacturer's instructions. After purification, the RNA samples were stored at $-80{ }^{\circ} \mathrm{C}$ until the following steps of the investigations.

\subsection{Primers}

22 The primers used in the present study were designed using the Primer Designer 4 software

23 (Scientific \& Educational Software, USA). Sequences of different vaccine and wild-type 
1 newly designed primers to the vaccine strains and wild-type strains as well. Primers were

2 synthesized by BIOMI Kft. (Gödöllö, Hungary).

\subsection{RT-PCR assays, RFLP and gel electrophoresis}

Reverse transcription and amplifications were performed in one-step RT-PCR method using

6 the QIAGEN OneStep RT-PCR Kit (Qiagen, Germany), according to the manufacturer's

7 instructions. Reverse transcription was carried out at $50{ }^{\circ} \mathrm{C}$ for $30 \mathrm{~min}$. Following an initial denaturation at $95{ }^{\circ} \mathrm{C}$ for $15 \mathrm{~min}$, the reaction mixture was subjected to 40 cycles of heat denaturation at $94{ }^{\circ} \mathrm{C}$ for $45 \mathrm{sec}$, the corresponding annealing temperature for each primer pair for $1 \mathrm{~min}$, and DNA extension at $72{ }^{\circ} \mathrm{C}$ for $2 \mathrm{~min}$, followed by a final extension of $10 \mathrm{~min}$ at $72{ }^{\circ} \mathrm{C}$. The reactions were performed in a SPRT001 PCR Sprint Thermal Cycler (Hybaid Ltd, UK).

Following RT-PCR $7.5 \mu \mathrm{l}$ of amplicons was electrophoresed at $80 \mathrm{~V}$ for $80 \mathrm{~min}$ in a 1.2\% Tris acetate-EDTA-agarose gel (Merck, Germany), stained with ethidium bromide. The bands were visualized by UV transillumination at $312 \mathrm{~nm}$. Product sizes were determined with reference to $100 \mathrm{bp}$ and $1 \mathrm{~kb}$ molecular weight ladders (Fermentas, Lithuania). The PsiI (SibEnzyme, Russia) based RFLP was carried out according to the previously described protocol (Demeter et al., 2007).

\subsection{Sequence analysis and phylogeny}

21 DNA was extracted from the gel with the QiaQuick Gel Extraction Kit (Qiagen, Germany). Fluorescence-based direct sequencings were performed in both directions on the amplicons by BIOMI Kft. (Gödöllő, Hungary) using an ABI 3100 genetic analyzer (Applied Biosystems, USA). Nucleotide sequences were identified by BLAST search against gene bank databases 
1 and aligned to the complete genome sequence of CDV using the Align Plus 4 software

2 (Scientific \& Educational Software, USA). The nucleotide sequences of the Vanguard vaccine

3 strain were deposited in the GenBank under the following accession numbers: EF095750 (H

4 gene), EU072198 (F gene), EU072199 (M gene), EU072200 (N gene) and EU072201 (P

5 gene). Phylogenetic trees of the nucleic acid and putative amino acid (aa) sequences were

6 established by using sequence data of the analyzed vaccine strains and the ones retrieved from the GenBank (most of the available complete sequences of the analyzed genes of vaccine and wild-type strains as well). In case of the Vanguard vaccine, each gene of the CDV genome was analyzed, except the highly conserved large polymerase (L) gene. Phylogenetic analyses were performed with the help of the ClustalX program and the robustness of the groupings in the neighbor-joining analysis was assessed with 1000 bootstrap resampling. Results of the phylogenetic analysis were verified using Bayesian and maximum likelihood (ML) approaches (Ronquist, F. \& Huelsenbeck, 2003) with the MrBayes 3.1.2 program. In order to identify any recombination the recombination detection program (RDP: http://darwin.uvigo.es/rdp/rdp.html) was used (Martin \& Rybicki, 2000).

\section{Results}

\subsection{RT-PCRs and RFLP analysis}

The RT-PCRs resulted amplicons of the expected size (Table 1) in case of every pair of primers used. The RFLP resulted two clearly differentiable bands in case of the currently used vaccine strains at the predicted heights of $294 \mathrm{bp}$ and $816 \mathrm{bp}$, while the amplicons obtained from field viruses and vaccines 1 to 6 (Table 1) remained undigested (1110 bp).

Different batches of Vanguard vaccines (Pfizer Animal Health, USA) dating back to 1992, 1994 and 2006 were also involved in the study. Furthermore, batches of the same brand 
1 States of America (Table 1). The RFLP test unequivocally resulted in undigested amplicons in

2 case of all batches from different time and geographical origin.

\subsection{Genetic analyses}

To identify the strain present in the Vanguard vaccines, primers were designed to cover more than half of the viral genome. The nucleotide sequences of all CDV genes, except the highly conserved L gene were determined. The genetic analyses of all investigated genes of the Vanguard vaccines (Table 1) have revealed that the virus strain present in all of them is more closely related to different wild-type strains from the America-2 group, than to the one stated by the manufacturer (Snyder Hill strain) or any of the viruses from the group of vaccine strains (Table 2). As a next step the full nucleotide sequences of the highly variable $\mathrm{H}$ gene of all vaccine brands currently used in Hungary were included in the study (Table 1). Since the obtained nucleotide sequences of vaccines 1 to 6 turned out to be $100 \%$ similar in case of all batches, the subsequent investigations performed on other domains of the virus genome were carried out using only vaccine number 6 . According to the investigation of the complete sequence of the $\mathrm{H}$ gene, the investigated virus strain was not positioned anywhere close to the Snyder Hill strain, but it showed a significantly higher similarity to a lesser panda isolate (99.45\%) and a wild-type strain (98.90\%) isolated from a naturally infected dog (strain 25259 , accession number: AY964114) in North America (Figure 1). As expected following the initial RFLP, the virus strains present in vaccines 7-10 were positioned in the group of vaccine 21 strains (America-1). The findings of the neighbour-joining method-based phylogenetic analysis were confirmed by the results of the Bayesian and ML methods as well: the Vanguard vaccine strain showed a considerably higher level of identity with wild-type viruses from the America-2 group (data not shown). RDP could not identify any recombination in case of any of the analyzed genes of the Vanguard vaccine strain (data not shown). 
The genetic analyses of the full nucleic acid sequences of the F, N, M and P genes

2 only confirmed the initial observations of the $\mathrm{H}$ gene analysis: in each case the virus strain

3 present in the Vanguard vaccine was not positioned in the group of vaccine strains (America-

4 1). Unfortunately the nucleic acid sequence of the Snyder Hill strain is not publicly available

5 for these genomic segments, except for a partial, 335 bps long F gene sequence: AY288312

6 and a 390 bps long partial P gene segment: AY286481. Even tough it cannot be considered as

7 reliable as complete gene sequence analyses, the genetic analysis of such small segments

8 yielded results identical with the initial investigations performed on the $\mathrm{H}$ gene.

9

\section{Discussion}

In the present study, we have applied a previously described PsiI-based RFLP test (Demeter et al., 2007) that theoretically allows the differentiation of all wild-type strains with known nucleotide sequence from all vaccine CDV strains. The differentiating RFLP analysis carried out on CD vaccine brands currently used in Hungary revealed that the CDV strain present in the Vanguard (Pfizer Animal Health, USA) vaccine reacted as a wild-type strain. According to the statement of the manufacturer, the European Vanguard products used to immunize dogs against CD contain the Snyder Hill strain. Based on the nucleotide sequence available in the GenBank (complete sequence of the $\mathrm{H}$ gene of the Snyder Hill strain: accession number: AF259552), the amplicons of the virus strain present in the Vanguard vaccine should have been digested by the $P$ siI enzyme, but they remained undigested, hence reacted as a wild-type virus. In order to elucidate the dilemma, an extensive genetic and phylogenetic analysis of the incriminated virus strain was conducted. Primer pairs that enabled the amplification of complete genes of the CDV genome were designed and the nucleotide sequences of all CDV genes $(\mathrm{H}, \mathrm{N}, \mathrm{M}, \mathrm{P}$ and $\mathrm{F})$, except the highly conserved $\mathrm{L}$ gene were determined. For phylogenetic purposes the $\mathrm{H}$ gene was chosen, because of its vital role in the infectious 
1 process (Murphy et al., 1999) this gene is considered as one of the most variable one in the

2 CDV genome (Haas et al., 1997; Harder \& Osterhaus, 1997; Iwastsuki et al., 1997;

3 Mochizuki et al., 1999; Uema et al., 2005; Martella et al., 2006, McCarthy et al., 2007),

4 therefore it is profoundly suitable for phylogenetic analysis. $\mathrm{H}$ gene analysis further

5 emphasized the previous findings: the investigated virus strain was not positioned anywhere

6 close to the Snyder Hill strain, but turned out to be most closely related to a wild-type virus

7 strain isolated from a lesser panda (AF178039). Similar observations were reported by another research group (Pardo et al., 2005), but the investigated segment was too small to obtain relevant results (979 bases). Based on the findings of this research group the virus strain present in the Vanguard vaccine was most closely related to the A75/17 wild-type strain isolated from a dog, but the investigation of the complete sequence of the $\mathrm{H}$ gene has revealed that it is more closely related to the lesser panda isolate $(99.45 \%)$ and a wild-type strain (98.90 \%) isolated in North America from a naturally infected dog (strain 25259, accession number: AY964114) by the same research group (Pardo et al., 2005). The analysis of other genes of CDV has only confirmed the findings of the $\mathrm{H}$ gene analysis. In order to extend our investigations in time and geographical respect, Vanguard vaccine vials produced in different time (1992 and 1994) and different geographical origin (Malta, Israel, and USA) were purchased and the same RFLP test was applied to determine whether these vaccines contain the same virus strain as the vaccine purchased in Hungary in 2006. The result of the RFLP test and the complete sequencing of the $\mathrm{H}$ gene of the virus strains present in all these Vanguard vaccine batches revealed that all of them contain exactly the same virus strain, showing not even one nucleotide difference on this relatively large and highly variable gene. Due to these findings, the vaccine batches dated back to 1992 and 1994 and the ones purchased in other countries were not investigated on other segments of the CDV genome, since those results most probably would have only confirmed the previous 
1 observations. On the other hand, these findings led to the conclusion that the Vanguard

2 vaccines have been containing the analyzed virus strain since at least 1992.

There could be several possible explanations for the findings of the present study, such

as (1) the incorrect labelling of the Snyder Hill strain deposited in the GenBank (AF259552) -

contradicted by its positioning among the group of vaccine strains in case of the phylogenetic

trees constructed based on the nucleic acid sequences of the full length of the $\mathrm{H}$ gene (Figure

1) and partial segment of the F gene (data not shown); (2) a possible recombination of the seed virus with a wild-type strain - this theory is eliminated by the simultaneous RDP-based analysis of several different genes; (3) due to a taxonomical and technical error (i.e. erroneous laboratory registries) the strain was incorrectly labelled when the vaccine was registered and finally (4) contamination of the seed virus stock used in the vaccine production, as also suggested by Pardo et al. (2005). At this point the last two explanations cannot be demonstrated neither eliminated. The significance of these findings is inconclusive without further studies, as phylogeny can not reveal whether or not a virus is virulent, and there may be little genetic distance between virus passages with dramatic changes in their phenotypes, including virulence. At this point it can only be declared that the vaccine does not contain the virus strain erroneously stated by the manufacturer in its product description and has not been containing it since at least as 1992 . Surely the vaccine strain underwent all the required tests before being licensed and proved to be safe to be used in animals, and no claims of inefficacy of the Vanguard vaccines have been reported. There are only a few reports of animals vaccinated with Vanguard vaccines that still developed clinical disease (McInnes et al., 1992; Pardo et al., 2005), but the exact cause of the lack of protection and the exact role of the vaccine strain in the infection was not elucidated, therefore no relevant conclusions can be drawn regarding the efficacy of the Vanguard vaccines, as there are numerous aspects that can interfere with the successful immunization of an animal (Povey, 1986; Greene \& Appel, 
1 2006). As no documented concerns regarding the safety and efficacy of the Vanguard strains

2 have been raised since at least 1992, it is possible that this recently and apparently 3 successfully attenuated wild-type strain could provide, at least theoretically, a better

4 protection against the currently circulating wild-type CDV strains.

On the other hand, these findings suggest that the previously described PsiI-based

6 identification of America-1 (vaccine) strains could lead to diagnostically false results in case

7 of animals recently vaccinated with any Vanguard vaccine, or in case of animals with uncertain vaccination history that could have been vaccinated with a Vanguard vaccine.

9

\section{Acknowledgements} product descriptions as N-CDV.

\section{Follow-up}

Following the notification of the research group, the manufacturer has performed the sequencing of the vaccine master-seed strain used globally for the production of the vaccine. The work has resulted in a regulatory review of, and a change in, the strain designation in the product literature globally in early 2009. This work demonstrated that the distemper strain used in vaccine production was misidentified back in 1956 when it was first acquired. Documentary evidence of these findings was supplied to the European regulatory agencies, and they have accepted the evidence of the misclassification, and the integrity of the registration study data and subsequent production batches. The strain is now identified in the 


\section{References}

Appel, M.J.G., 1987. Canine distemper virus. In: Horzinek MC, editor. Virus infections of carnivores, Vol. 1. Amsterdam, Elsevier, pp. 133-159.

Barrett, T., 1999. Morbillivirus infections, with special emphasis on morbilliviruses of carnivores. Vet. Microbiol. 69, 3-13.

Blixenkrone-Møller, M., Svansson, V., Have, P., Orvell, C., Appel, M., Pedersen, I.R., Dietz, H.H., Henriksen, P., 1993. Studies on manifestations of canine distemper virus infection in an urban dog population. Vet. Microbiol. 37, 163-173.

Brown, A.L., Vitamvas, J.A., Merry, D.L. Jr., Beckenhauer, W.H., 1972. Immune response of pups to modified live-virus canine distemper-measles vaccine. Am. J. Vet. Res. 33, 14471456.

Calderon, M.G., Remorini, P., Periolo, O., Iglesias, M., Mattion, N., La Torre, J., 2007. Detection by RT-PCR and genetic characterization of canine distemper virus from vaccinated and non-vaccinated dogs in Argentina. Vet. Microbiol. 125, 341-349.

Chappuis, G., Control of canine distemper. Veterinary Microbiol 1997; 44: 351-358.

Demeter, Z., 2009. Polymerase chain reaction based investigations of canine distemper and parvovirus strains from Hungary. Doctoral Thesis. Postgraduate School of Veterinary Science, Budapest, Hungary 
2 Demeter, Z., Palade, E.A., Lakatos, B., Kozma, T., Rusvai, M., 2006. Experiences on the

3 control of endemic distemper at the flaying-house of Budapest. Magyar Állatorvosok Lapja 4 128, 665-673. [in Hungarian]

6 Demeter, Z., Lakatos, B., Palade, E.A., Kozma, T., Forgách, P., Rusvai, M., 2007. Genetic 7 diversity of Hungarian canine distemper virus strains. Vet. Microbiol. 122, 258-269.

9 Gemma, T., Watari, T., Akiyama, K., Miyashita, N., Shin, Y.S., Iwatsuki, K., Kai, C.,

Mikami, T., 1996. Epidemiological observations on recent outbreaks of canine distemper in

11 Tokyo area. J. Vet. Med. Sci. 58, 547-550.

12

Greene, C.E., Appel, M.J., 2006. Canine distemper. In: Greene CE, editor: Infectious diseases

of the dog and cat, $3^{\text {rd }}$ edition. Saunders-Elsevier, pp. 25-41.

Haas, L., Martens, W., Greiser-Wilke, I., Mamaev, L., Butina, T., Maack, D., Barrett, T., 1997. Analysis of the haemagglutinin gene of current wild-type canine distemper virus isolates from Germany. Virus Res. 48, 165-171.

Haig, D.A., 1956. Canine distemper: immunization with avianized virus. Onderstepoort 21 Journal of Veterinary Research 17, 19-53.

Han, G.Z., Liu, X.P., Li, S.S., 2008. Cross-species recombination in the haemagglutinin gene of canine distemper virus. Virus Res. 136, 198-201. 
1 Harder, T.C., Osterhaus, A.D.M.E., 1997. Canine distemper virus - A morbillivirus in search

2 of new hosts? Trends Microbiol. 5, 120-124.

3

4 Iwatsuki, K., Miyashita, N., Yoshida, E., Gemma, T., Shin, Y.S., Mori, T., Hirayama, N., Kai,

5 C., Mikami, T., 1997. Molecular and phylogenetic analyses of the haemagglutinin (H)

6 proteins of field isolates of canine distemper virus from naturally infected dogs. J. Gen. Virol.

$7 \quad 78,373-280$.

8

9 Kabakci, N., Yarim, M., Karahan, S., Guvenc, T., Yagci, B.B., Gurcan, I.S., 2004.

10 Immunohistochemical investigation of cerebellum in dogs infected with canine distemper

11 virus. Acta Vet. Hung. 52, 327-337.

12

Kai, C., Ochikubo, F., Okita, M., Iinuma, T., Mikami, T., Kobune, F., Yamanouchi, K., 1993.

Use of B95a cells for isolation of canine distemper virus from clinical cases. J. Vet. Med. Sci. $55,1067-1070$.

16

Lan, N.T., Yamaguchi, R., Inomata, A., Furuya, Y., Uchida, K., Sugano, S., Tateyama, S., 2006. Comparative analyses of canine distemper viral isolates from clinical cases of canine distemper in vaccinated dogs. Vet. Microbiol. 115, 32-42.

Lednicky, J.A., Dubach, J., Kinsel, M.J., Meehan, T.P., Bocchetta, M., Hungerford, L.L., Sarich, N.A., Witecki, K.E., Braid, M.D., Pedrak, C., Houde, C.M., 2004. Genetically distant American canine distemper virus lineages have recently caused epizootics with somewhat different characteristics in raccoons living around a large suburban zoo in the USA. Virology $\mathrm{I}-2,1-14$. 
2 Martella, V., Cirone, F., Elia, G., Lorusso, E., Decaro, N., Campolo, M., Desario, C., Lucente,

3 M.S., Bellacicco, A.L., Blixenkrone-Møller, M., Carmichael, L.E., Buonavoglia, C., 2006.

4 Heterogeneity within the hemagglutinin genes of canine distemper virus (CDV) strains

5 detected in Italy. Vet. Microbiol. 116: 301-309.

6

7 Martella, V., Elia, G., Buonavoglia, C., 2008. Canine distemper virus. Vet. Clin. N. Am. $8 \quad$ Small 38, 787-797.

9

Martella, V., Elia, G., Lucente, M.S., Decaro, N., Lorusso, E., Bányai, K., Blixenkrone-

11 Møller, M., Lan, N.T., Yamaguchi, R., Cirone, F., Carmichael, L.E., Buonavoglia, C., 2007.

12 Genotyping canine distemper virus (CDV) by a hemi-nested multiplex PCR provides a rapid approach for investigation of CDV outbreaks. Vet. Microbiol. 122, 32-42.

14

Martin, D., Rybicki, E., 2000. RDP: detection of recombination amongst aligned sequences.

Bioinformatics 16, 562-563.

17

McCarthy, A.J., Shaw, M.A., Goodman, S.J., 2007. Pathogen evolution and disease emergence in carnivores. Proc. R. Soc. B. 274, 3165-3174.

21 McInnes, E.F., Burroughs, R.E.J., Duncan, N.M., 1992. Possible vaccine-induced canine 22 distemper in a South American bush dog (Speothos venaticus). J. Wildlife Dis. 28, 614-617. 
1 Mochizuki, M., Hashimoto, M., Hagiwara, S., Yoshida, Y., Ishiguro, S., 1999. Genotypes of

2 canine distemper virus determined by analysis of the hemagglutinin genes of recent isolates

3 from dogs in Japan. J. Clin. Microbiol. 37, 2936-2942.

4

5 Murphy, F., Gibbs, J., Horzinek, M., Studdert, J., 1999. Veterinary Virology, 3rd edition, San 6 Diego, CA, USA, Academic Press

7

8

9 RT-PCR. J. Vet. Med. Sci. 57, 439-445. 5009-5017. prophylaxis. Vaccine 27, 491-504.

Can. Vet. J. 27, 321-323. mixed models. Bioinformatics 19, 1572-1574.

Pardo, I.D., Johnson, G.C., Kleiboeker, S.B., 2005. Phylogenetic characterization of canine distemper viruses detected in naturally infected dogs in North America. J. Clin. Microbiol. 43,

Patel, J.R., Heldens, J.G.M., 2009. Review of companion animal viral diseases and

Povey, R.C., 1986. Distemper vaccination of dogs: factors which could cause vaccine failure.

Ronquist, F., Huelsenbeck, J. P., 2003. MrBayes 3: Bayesian phylogenetic inference under

Shin, Y.S., Mori, T., Okita, M., Gemma, T., Kai, C., Mikami, T., 1995. Detection of canine distemper virus nucleocapsid protein gene in canine peripheral blood mononuclear cells by 
1 Uema, M., Ohashi, K., Wakasa, C., Kai, C., 2005. Phylogenetic and restriction fragment

2 length polymorphism analyses of hemagglutinin $(\mathrm{H})$ protein of canine distemper virus isolates

3 from domestic dogs in Japan. Virus Res. 109, 59-63.

4 
1 Figure 1: Phylogenetic tree constructed based on a total number of 165 complete nucleotide

2 sequences (1824 bp) of the $\mathrm{H}$ gene. In case of each strain the accession number along with the 3 species and country of origin is presented (when applicable).

4 * result of a recombination between an "Asia-1" and an "European wildlife" strain (Han et al., $52008)$ 
Figure 1

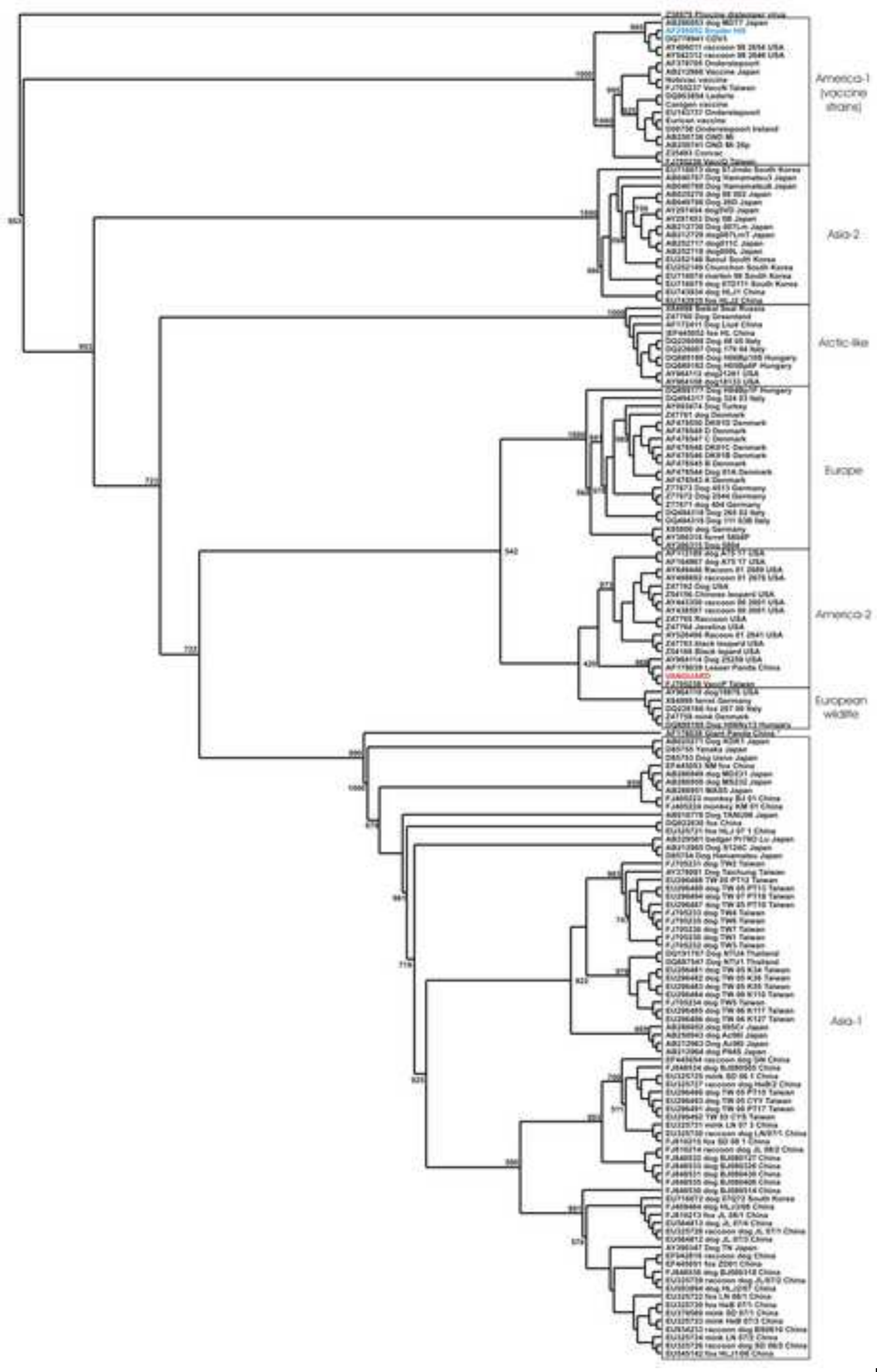


Table 1: Description of the vaccines used in the present study

\begin{tabular}{|c|c|c|c|c|c|}
\hline & Vaccine brand & Manufacturer & Batch number & $\begin{array}{c}\text { Year of } \\
\text { production }\end{array}$ & $\begin{array}{c}\text { Country of } \\
\text { origin }\end{array}$ \\
\hline 1 & Vanguard & Norden Laboratories & $\mathrm{NA}^{\mathrm{a}}$ & 1992 & Hungary \\
\hline 2 & Vanguard & Smith Kline & $\mathrm{NA}^{\mathrm{a}}$ & 1994 & Hungary \\
\hline 3 & Vanguard Plus 5 & Pfizer Animal Health & L53665 & 2006 & Hungary \\
\hline 4 & Vanguard Plus 5 & Pfizer Animal Health & A602088C & 2006 & Israel \\
\hline 5 & Vanguard Plus 7 & Pfizer Animal Health & L60065 & 2006 & Malta \\
\hline 6 & Vanguard Plus 5 & Pfizer Animal Health & A602620B & 2006 & USA \\
\hline 7 & Canigen DH(A2)PPi & Ceva Sante Animale & $12 \mathrm{TU}$ & 2006 & Hungary \\
\hline 8 & Eurican & Merial & L246779 & 2006 & Hungary \\
\hline 9 & Nobivac DHP & Intervet & $\mathrm{A} 030 \mathrm{C} 01$ & 2006 & Hungary \\
\hline 10 & Canvac 8 & Dyntec & 040407 & 2007 & Hungary \\
\hline
\end{tabular}


Table 2: The level of identity between the nucleotide and amino acid sequence of the $\mathrm{H}$ gene and $\mathrm{H}$ protein of the strain present in the Vanguard vaccines and those of the viruses from the group of vaccine strains (shaded) and of the wild-type strains, which showed the highest level of identity and the Snyder Hill strain (bolded). The values in italic represent the level of identity at the amino acid level.

\begin{tabular}{cccccccccc}
\hline & Vanguard & Panda & Dog & Snyder Hill & Convac & Canigen & Onder. & Eurican & Japan \\
\hline Vanguard & - & $\mathbf{9 8 . 8 4}$ & $\mathbf{9 8 . 3 5}$ & $\mathbf{9 1 . 7 7}$ & 90.95 & 90.95 & 91.44 & 90.13 & 91.44 \\
Panda & $\mathbf{9 9 . 4 5}$ & - & 97.86 & 91.61 & 91.44 & 90.78 & 91.28 & 89.96 & 91.28 \\
Dog & $\mathbf{9 8 . 9 0}$ & 98.57 & - & 90.78 & 89.96 & 89.96 & 90.46 & 89.14 & 90.46 \\
Snyder Hill & $\mathbf{9 2 . 9 2}$ & 92.70 & 92.32 & - & 95.39 & 95.23 & 95.72 & 93.91 & 95.72 \\
Convac & 93.09 & 93.31 & 92.48 & 97.09 & - & 96.87 & 97.53 & 95.55 & 97.36 \\
Canigen & 93.03 & 92.81 & 92.43 & 96.87 & 98.46 & - & 99.01 & 98.19 & 99.17 \\
Onder. & 93.25 & 93.03 & 92.65 & 97.09 & 98.68 & 99.39 & - & 97.69 & 99.50 \\
Eurican & 92.59 & 92.37 & 91.99 & 96.32 & 97.91 & 99.23 & 98.84 & - & 97.69 \\
Japan & 93.25 & 93.03 & 92.65 & 97.09 & 98.68 & 99.45 & 99.61 & 98.90 & - \\
\hline
\end{tabular}

Vanguard: EF095750; Snyder Hill: AF259552; Convac: Z35493; Canigen: DQ903854; Onder: AF378705, Eurican: AF014953; Japan: AB212966; Panda (Lesser Panda): AF178039; Dog (25259): AY964114 